\title{
Método simple para determinar el módulo de Young dinámico a partir de una excitación por impacto aplicado a morteros de cal y cemento
}

\section{Simple method of dynamic Young's modulus determination in lime and cement mortars}

\author{
J. R. Rosell(*), I. R. Cantalapiedra(*)
}

Recepción/Received: 10-VII-09

Aceptación/Accepted: 17-XII-09

Publicado online/Online publishing: 15-VII-10

\section{RESUMEN}

El presente trabajo muestra un método simple para determinar el módulo de Young dinámico (MOE) a partir de pequeñas perturbaciones mecánicas producidas a probetas de mortero de cal y de cemento, correlacionando los resultados obtenidos con las correspondientes mediciones realizadas con otras técnicas.

El procedimiento sigue básicamente las instrucciones fijadas en la Norma UNE-EN ISO 12680-1 (8) de productos refractarios, pero aplicándolo a probetas normalizadas RILEM 4x4×16 cm de morteros confeccionados con cal y cemento.

Paralelamente se realizan determinaciones del MOE a partir de la velocidad de paso de impulsos ultrasónicos y determinaciones del módulo de Young estático a partir de ensayos de flexión convencionales.

La simplicidad del método aplicado y la correlación de los resultados obtenidos con las variables medidas permiten concluir que esta metodología es de aplicación directa para determinar la deformabilidad bajo carga de los morteros a partir de probetas normalizadas.

Palabras clave: cal, mortero, módulo de Young, ENDensayo no destructivo.

\section{SUMMARY}

The present work explains a simple method to determine the dynamic Young module (MOE) by inducing a set of small mechanical perturbation to samples of lime and cement mortars and correlating the results obtained with results determined using other techniques and methods.

The procedure described herein follows the instructions stated in the UNE-EN ISO 12680-1(8) standard for refractory products although in this study the instructions are applied to standardized RILEM $4 \times 4 \times 16 \mathrm{~cm}$ test samples made of lime and cement mortars.

In addition, MOE determinations are obtained by using ultrasonic impulse velocity while static Young's modulus determinations are obtained by performing conventional bending tests.

The ability of this procedure to correlate with results from other techniques, along with its simplicity, suggests that it can be widely adapted to determine the deformability of mortars under load using standardized samples.

Keywords: lime, mortar, Young's modulus, NDT-non destructive test.

(*) Universitat Politècnica de Catalunya (Barcelona, España).

Persona de contacto/Corresponding author: joan.ramon.rosell@upc.edu 


\section{INTRODUCCIÓN}

En el ámbito de los trabajos de restauración de edificaciones, resulta de especial interés conocer el comportamiento deformacional bajo tensión de los morteros. Por ejemplo, determinados morteros hacen rígidos en exceso los elementos edificatorios y, en consecuencia, varían el comportamiento estructural del conjunto (1).

Así, uno de los parámetros fundamentales en la resistencia de materiales y especialmente entre los materiales de construcción es el módulo de Young, que se obtiene a partir del cociente que relaciona la tensión unitaria aplicada y la deformación unitaria obtenida en su tramo elástico-lineal, en un proceso de variación de estado tensional.

Los métodos habituales que se realizan en laboratorio para determinar dicho módulo se basan en ensayos estáticos que permiten medir con precisión tensiones y deformaciones, o en la aplicación de ondas acústicas que determinan el módulo dinámico de una forma simple y económica.

Otro grupo de técnicas de ensayo, basadas en la aplicación de ondas acústicas generadas a partir de impactos, han sido utilizadas con éxito en otros campos como el de la madera $(2,3)$, los hormigones $(4,5)$ y los polímeros $(6)$.

Estos ensayos no destructivos evitan las roturas del material o de las probetas confeccionadas para su estudio, proporcionando un conjunto de resultados interesantes por sí mismos y para su contraste en la estimación de otros parámetros del material.

Para algunos materiales específicos, como la piedra natural (7) y los productos refractarios (8), existen normas para determinar su módulo de Young dinámico (MOE) a partir de la aplicación de técnicas de análisis de su frecuencia propia de resonancia. Sin embargo, en el campo de los morteros esta acción de normalización no se ha producido.

El objetivo principal de este artículo es validar una metodología de ensayo no destructivo, en su aplicación a los morteros comunes de cal y cemento.

\section{MATERIALES Y ENSAYOS}

El presente trabajo proporciona unos primeros resultados que permiten valorar la aplicación de un ensayo nodestructivo basado en el análisis de la frecuencia de resonancia en el ámbito de los morteros. Dicho ensayo se ha realizado a partir de unos elementos muy simples y económicos.

\section{INTRODUCTION}

In the field of building restoration works, it is especially relevant to know how mortars behave under stress. For instance, some mortars stiffen up buildings, and therefore, they modify their structural behavior as a whole (1).

Thus, one of the fundamental parameters in the resistance of materials, especially those used in construction, is the Young's modulus, which is the ratio of stress to the strain obtained in the linear elastic span through a range of variations in the tensional state.

The methods for determining the mentioned modulus that are usually employed in the laboratory are based upon static tests which accurately measure stress and strain, or on acoustic waves which determine the dynamic modulus in a simple and inexpensive manner.

Another set of techniques, based on the application of acoustic waves proceeding from impacts, has been successfully used in other fields such as the study of woods $(2,3)$, concretes $(4,5)$ and polymers (6).

These non-destructive tests prevent the breaking of the material or the samples, and they provide a set of results which are not only interesting in themselves, but they can also be used to estimate other materials' parameters.

For some specific materials, like natural stones (7) and refractory products (8), there are norms for the determination of their dynamic Young modulus (MOE) that use analysis techniques based on the material's own resonance frequency. However, no norms for mortars exist in this sense.

This research attempts to validate a non-destructive test methodology for common lime cement mortars.

\section{MATERIALS AND TESTS}

The present work provides some preliminary results for evaluating the application of a non-destructive test based on the analysis of the resonant frequency in mortars. The test has been performed with very simple and inexpensive equipment. 
Para este fin, se han ejecutado diferentes ensayos:

- Ensayo de determinación del MOE por excitación de la vibración por impacto y posterior análisis de la frecuencia fundamental de resonancia.

- Ensayo de determinación del MOE a partir de la velocidad de paso de impulsos ultrasónicos.

- Ensayo de flexión estática para obtener el tramo lineal de la gráfica tensión-deformación.

Los resultados de ambos MOE se han alcanzado bajo presunciones necesariamente simplificadas, dado que las expresiones utilizadas en los cálculos de módulo de Young son válidas en medios isótropos y homogéneos, mientras que el mortero de cal no cumple estrictamente esta condición.

\subsection{Morteros a ensayar}

El ensayo de análisis de la frecuencia de resonancia, se aplica sobre probetas normalizadas según RILEM de formato $4 \times 4 \times 16 \mathrm{~cm}$. Los morteros realizados son de 8 tipologías diferentes según la dosificación de los conglomerantes y de las arenas (Tabla 1 ).
Several tests have been run for that purpose:

- MOE (dynamic elasticity modulus of elasticity) determination test by impulse excitation of vibration and the subsequent analysis of the resonant basic frequency.

- MOE determination test from the velocity at which ultrasonic impulses propagate through the sample.

- Static flexural test to obtain the linear region of the stretch-deformation graph.

The results on both MOE have been obtained using necessarily simplified assumptions since the expressions used in the estimation of the Young's modulus are valid in both isotropic and homogeneous media, whereas lime mortars do not comply strictly with this condition.

\subsection{Mortars to be tested}

The resonance frequency analysis test is applied on standard $4 \times 4 \times 16 \mathrm{~cm}$ RILEM samples. The studied mortars belong to eight different categories depending on the dosage of binders and sands (Table 1).

Tabla 1 / Table 1

Nomenclatura y dosificaciones.

Nomenclature and dosages.

\begin{tabular}{|c|c|c|c|c|c|c|c|}
\hline \multirow{2}{*}{ Código / Code } & \multicolumn{3}{c|}{ Conglomerantes / Binders } & \multicolumn{2}{c|}{ Áridos / Aggregates } & Agua / Water \\
\cline { 3 - 8 } & & CL 90-S & NHL 3.5 & CEM I 42.5 & $\mathbf{6 0 0} \boldsymbol{\mu m}$ & $\mathbf{3 6 0 0} \boldsymbol{\mu m}$ & $\begin{array}{c}\text { Agua/sólido / } \\
\text { W./sol }\end{array}$ \\
\hline NHL3.5 & $1: 2.7-600$ & & 1 & & 2.7 & & 0.19 \\
\hline NHL3.5 & $1: 4-600$ & & 1 & & 4 & & 0.19 \\
\hline NHL3.5 & $1: 2.7-3600$ & & 1 & & & 2.7 & 0.15 \\
\hline NHL3.5 & $1: 4-3600$ & & 1 & & & 4 & 0.14 \\
\hline CC & $1: 2.7-600$ & 0.6 & & 0.4 & 2.7 & & 0.24 \\
\hline CC & $1: 4-600$ & 0.6 & & 0.4 & 4 & & 0.22 \\
\hline CC & $1: 2.7-3600$ & 0.6 & & 0.4 & & 2.7 & 0.20 \\
\hline CC & $1: 4-3600$ & 0.6 & & 0.4 & & 4 & 0.18 \\
\hline
\end{tabular}

Se utilizan dos tipos de conglomerantes: cal hidráulica $\mathrm{NHL} 3,5$ y la mezcla de cal aérea CL $90-\mathrm{S}$ más cemento Portland CEM I 42,5; y dos mezclas de áridos comerciales de origen calcáreo de curvas granulométricas ajustadas a Fuller, que responden a la composición especificada en la Tabla 2.
Two types of binders have been used: hydraulic lime NHL 3.5 and a mix of air lime CL 90-S with portland cement CEM I 42.5 and two mixtures of commercial calcareous aggregates with adjusted Fuller curves, corresponding to the specified composition stated in Table 2.

Tabla 2 / Table 2

Composición mineralógica de los áridos.

Mineralogical composition of aggregates.

\begin{tabular}{|c|c|c|c|c|c|}
\hline $\begin{array}{c}\text { Designación áridos I } \\
\text { Aggregates designation }\end{array}$ & $\begin{array}{c}\text { Tamaño máximo (mm) I } \\
\text { Max size (mm) }\end{array}$ & $\mathbf{C O}_{3} \mathrm{Ca}$ & $\mathbf{M g C O}_{3}$ & $\begin{array}{c}\text { Insolubles en } \mathrm{CIH}_{\text {I }} \\
\text { Insoluble in ClH }\end{array}$ \\
\hline $600 \mu \mathrm{m}$ & 0.6 & $\geq 98 \%$ & $<0.8 \%$ & $<0.05 \%$ & $<0.8 \%$ \\
\hline $3600 \mu \mathrm{m}$ & 3.6 & $\geq 99 \%$ & $<0.3 \%$ & $<0.02 \%$ & $<0.2 \%$ \\
\hline
\end{tabular}


La cantidad de agua para el amasado se ha definido por un asentamiento en mesa de sacudidas de $155 \pm 5 \mathrm{~mm}$ según Norma (9) y el proceso de curado ha seguido el siguiente calendario:

- 7 días en ambiente saturado en cámara húmeda (HR > 95\% y $20 \pm 2{ }^{\circ} \mathrm{C}$ ).

- 21 días en ambiente de laboratorio (HR 50\% \pm 5 y $\left.20 \pm 2{ }^{\circ} \mathrm{C}\right)$.

- Secado en estufa a $60^{\circ} \mathrm{C}$ hasta peso constante.

\subsection{Determinación de los módulos de Young}

Se determina el peso de cada probeta con una balanza de precisión de 0,01 g y las mediciones de su longitud, anchura y espesor mediante un calibrador (tipo pie de rey de precisión $0,01 \mathrm{~mm}$ ) para así hallar la densidad aparente de cada uno de los tipos de mortero que conforman las probetas.

\section{- MOE longitudinal por impacto (MOE long $_{\text {) }}$}

La tarea principal es la obtención del modo fundamental de la frecuencia propia de resonancia, mediante la aplicación de un impulso instantáneo (golpeo) sobre la probeta y la recogida de la señal o espectro de frecuencias que este golpeo produce. La señal se analiza mediante la transformada rápida de Fourier (FFT) con la ayuda de un software adecuado.

En la Figura 1 vemos el esquema del equipo, coincidente con el diagrama de bloques del dispositivo según Norma (8).
The quantity of kneading water has been determined by a settlement in a $155 \pm 5 \mathrm{~mm}$ shaking table according to standard (9), and the curing process has followed this schedule:

- 7 days in a saturated environment in a wet chamber (R.H. $>95 \%$ and $20 \pm 2{ }^{\circ} \mathrm{C}$ ).

- 21 days in laboratory environment ( $R H 50 \% \pm 5$ and $\left.20 \pm 2^{\circ} \mathrm{C}\right)$.

- Drying in a mould dryer at $60{ }^{\circ} \mathrm{C}$ until even weight has been reached.

\subsection{Young's modulus determination}

The weight of each sample is determined by a precision balance of $0.01 \mathrm{~g}$. The length, width, and thickness are determined by using a gauge (such as the slide-gage of $0.01 \mathrm{~mm}$ ) in order to find out the apparent density of each of the mortar types of the samples.

\section{- Longitudinal MOE by impact (MOE $\left.{ }_{\text {long }}\right)$}

The most important task is to obtain the fundamental mode resonant frequency when the specimen is subjected to an instantaneous pulse (beating) and to register the signal or the frequency spectrum that this beating produces. The signal is analyzed by Fast Fourier Transform (FFT) with adequate software.

Figure 1 shows the equipment used, matching the diagram of blocks of the device as shown in (8).

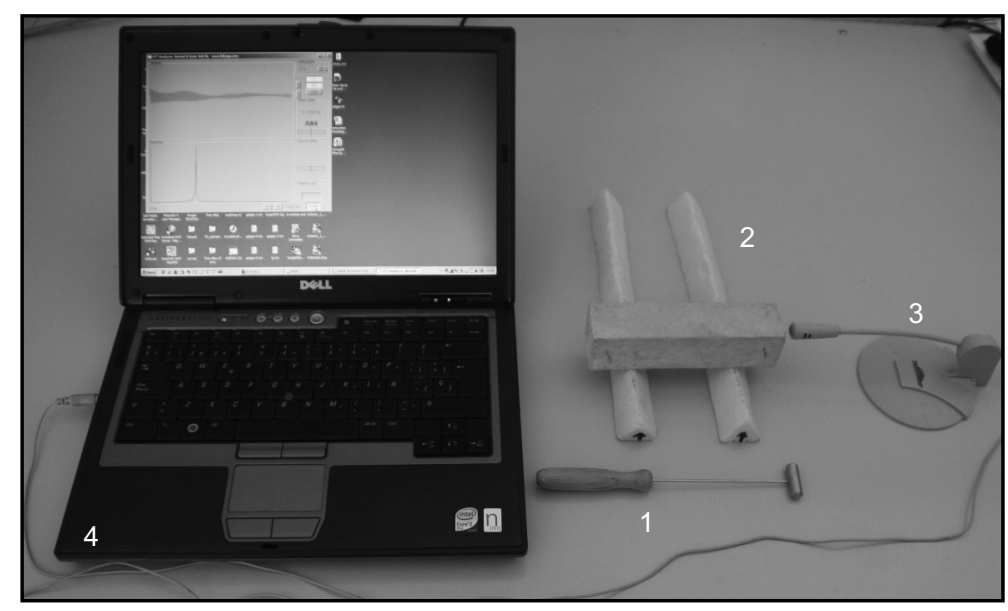

Figura 1. Equipo para determinar MOE por impacto.

Figure 1. Equipment for determining MOE by impact.

Siguiendo dicho esquema el dispositivo consta de:

1. Elemento o martillo percutor: su punta puede ser de acero o madera dura y su peso debe ser tal que evite
As the diagram shows, the device is composed of:

1. A plexor with an end made of steel or hardwood; its weight has to be suitable for preventing a physical 
un desplazamiento físico de las probetas en el momento del golpeo; se considera un peso aproximado del martillo percutor de un $5 \%$ del peso de la probeta.

2. Elementos de soporte de las probetas o muestras a ensayar: los soportes ejercen una importante función, ya que aíslan las probetas de mortero de las vibraciones externas y, según su colocación, definen el modo de vibración de las muestras (Figura 2a). Los soportes utilizados son de poliestireno extrusionado de densidad $35 \mathrm{~kg} / \mathrm{m}^{3}$, en forma de prisma triangular de $3 \mathrm{~cm}$ de lado. movement of the specimens when the beating is produced. Appropriate plexor weight has to be $5 \%$ of the specimen weight.

2. Items for supporting the specimens or test samples. The role of the holders in this method is very important since they isolate mortar specimens from external vibrations and their position defines the vibration mode of the samples (Figure 2a).

The holders being used are made of triangular prisma-shaped extrusioned polystyrene of $35 \mathrm{~kg} / \mathrm{m}^{3}$ density and with sides of $3 \mathrm{~cm}$.

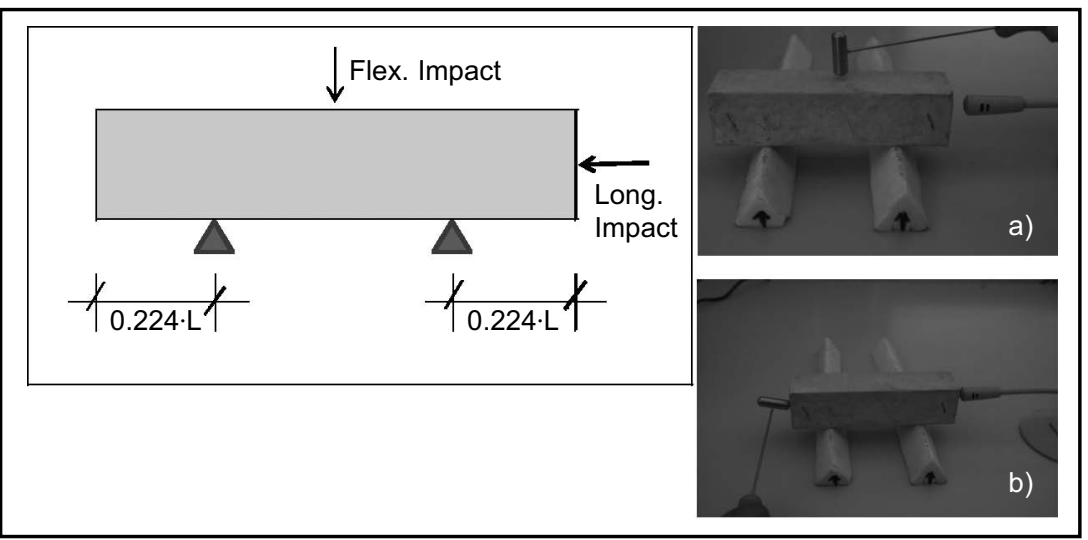

Figura 2. Esquema de la disposición de los apoyos y las zonas de impacto (a) para $\mathrm{MOE}_{\text {flex }}$ y (b) para $\mathrm{MOE}_{\text {long }}$. Figure 2. Image of the position of holders and impact zones (a) for $M O E_{f l e x}$ and (b) for $M O E_{\text {long. }}$

3. Elemento de captación de señal (micrófono): utilizaremos transductores de señal sin contacto para evitar posibles errores de medición causados por las vibraciones parásitas que puedan generarse por pequeños desplazamientos en las probetas. Estos transductores se colocan en los puntos de antinodo a una distancia entre 3 y $10 \mathrm{~mm}$ de la superficie de la probeta.

Las lecturas se realizan en condiciones climáticas de laboratorio ( $20 \pm 2{ }^{\circ} \mathrm{C} ; 60 \pm 10 \% \mathrm{HR}$ ) y en condiciones de ausencia de ruidos estridentes, pero sin especiales restricciones de silencio.

4. Sistema de tratamiento de la señal: consta de acondicionador/amplificador de señal y software de análisis del espectro obtenido.

A partir del valor de la frecuencia fundamental de resonancia correspondiente, $\mathrm{f}$ en $\mathrm{Hz}$, de la longitud de onda del primer armónico, $2 \mathrm{~L}$ en $\mathrm{m}$, obtenemos la velocidad de la pulsación, $v$ en $\mathrm{m} / \mathrm{s}$ [1]
3. Signal register device (microphone). Non-contact signal transducers have been used in this study in order to prevent miscalculations caused by the flutters that could be generated by the slightest movement of the samples. The transducers must be placed in the antinode points 3 to $10 \mathrm{~mm}$ away from the surface of the sample.

The readings are taken at room temperature (20 \pm $2{ }^{\circ} \mathrm{C} ; 60 \pm 10 \% \mathrm{HR}$ ) in the absence of loud noises, but without any special sound restriction conditions.

4. Signal processing system. This is composed of: signal conditioner/amplifier and software for the analysis of the obtained spectrum.

From the value of the corresponding resonant frequency, $f$ given in $\mathrm{Hz}$, of the first harmonic's wavelength, $2 \mathrm{~L}$ in $\mathrm{m}$, we can obtain the pulse velocity, $v$ in $m / s$ [1]

$$
v=2 L f
$$

$\mathrm{L}=$ longitud de la probeta $(0,160 \mathrm{~m}) / \mathrm{L}=$ sample's length $(0.160 \mathrm{~m})$

$\mathrm{f}=$ frecuencia fundamental de resonancia $/ f=$ resonance frequency 
y utilizando el valor de la densidad, $\rho$ en $\mathrm{kg} / \mathrm{m}^{3}$, calculamos el valor del $\mathrm{MOE}_{\text {long }}$ [2] and using the density value, $\rho$ en $\mathrm{kg} / \mathrm{m}^{3}$, it is possible to calculate the $M O E_{\text {long }}$ value: [2]

$$
\begin{gathered}
\mathrm{MOE}_{\text {long }}=\rho \mathrm{v}^{2} \\
\rho=\text { densidad de la probeta } / \rho=\text { density }
\end{gathered}
$$

El valor utilizado como frecuencia de resonancia es el valor medio de seis lecturas obtenidas consecutivamente con una diferencia máxima entre ellas del $1 \%$.

\section{- MOE flexión por impacto $\left(\mathrm{MOE}_{\mathrm{flex}}\right)$}

Consecutivamente se realizan lecturas de las frecuencias de resonancia a flexión (Figura $2 \mathrm{a}$ ) apoyando las probetas en la cara correspondiente al fondo del molde (cara 1), girándolas 90 grados y apoyadas en una cara lateral del molde (cara 2). Se siguen las especificaciones descritas en la norma (8), referentes a condiciones de los apoyos, cálculos de resultados, etc. Se ha supuesto un coeficiente de Poisson de 0,22.

\section{- MOE longitudinal por ultrasonido $\left(\mathrm{MOE}_{\mathrm{us}}\right)$}

Para esta determinación se ha utilizado un equipo de emisión-recepción de ultrasonidos C368 de Matest, provisto de palpadores de contacto receptor-transmisor de $55 \mathrm{kHz}$. Las lecturas de tiempo de paso se han realizado en sentido longitudinal de la probeta.

Se ha determinado la velocidad de paso $\left(\mathrm{v}_{\mathrm{us}}\right)$ [3]

The value we use as resonant frequency is the average value of six successive readings obtained with a maximum difference of $1 \%$ between them.

\section{- Flexural MOE (MOE flex $)$ by impact}

Holding the specimens in the corresponding face to the bottom of the mould (face 1), and rotating them 90 degrees and holding them in a lateral side of the mould (face 2), successive readings of the flexural resonant frequencies are made (Figure 2a). Specifications described in standard (8) referring to the conditions of the holders, results calculations, etc., have been followed. It is considered a 0.22 Poisson's ratio.

\section{- Longitudinal MOE (MOE $\left.{ }_{u s}\right)$ by ultrasound}

A transmitting and receiving appliance of ultrasound C368 made by Matest, was used for this determination. This appliance has $55 \mathrm{kHz}$ transceiver sensors. The time it takes the ultrasonic pulse to go through the test sample in the longitudinal direction has been measured.

The velocity of the longitudinal propagation of ultrasonic waves through the specimen $\left(V_{u s}\right)$ has been determined as [3].

$$
\mathrm{v}_{\mathrm{us}}=\mathrm{L} / \mathrm{t}
$$

$\mathrm{L}=$ longitud de la probeta $(0,160 \mathrm{~m}) / \mathrm{L}=$ sample's length $(0.160 \mathrm{~m})$

$\mathrm{T}=$ tiempo de paso (s) / $T=$ time it takes the ultrasonic waves to go through the sample (s)

Se ha determinado el MOE longitudinal por ultrasonido a partir de la expresión (10) [4]:
Longitudinal MOE by ultrasound has been calculated with the expression (10) [4]:

$$
\begin{gathered}
\mathrm{MOE}_{\mathrm{us}}=\rho(1+\mu)(1-2 \mu) \mathrm{v}_{\mathrm{us}}{ }^{2} /(1-\mu) \\
\mu=\text { Coeficiente de Poisson } / \mu=\text { Poisson coefficient }
\end{gathered}
$$

\section{- Módulo de Young estático por flexotracción, E}

Para determinar el módulo de Young estático se ha procedido a instrumentar las probetas con galgas extensométricas y a ensayarlas a flexión, procediendo mediante

\section{- Static Young modulus by flexotraction, E}

The procedure to determine static Young's modulus has been to manipulate specimens with strain gauges and carry out flexural tests by means of load increments until 
pequeños incrementos de carga hasta la estabilización de las señales correspondientes de tensión de tracción y de deformación unitaria $(\sigma, \varepsilon)$. La regresión lineal en la zona inicial del gráfico tensión-deformación permite determinar el módulo de Young.

Para facilitar una mayor zona de flexión pura constante se ha procedido mediante un sistema de aplicación de carga en dos puntos (Figura 3). stabilization of tensile strength and strain $(\sigma, \varepsilon)$ signal is attained. Linear regression in the initial zone of the stress-strain graph allows determining the Young's modulus.

With the purpose of facilitating a larger flexural zone, pure and constant, a proof loading system in two points has been used (Figure 3).

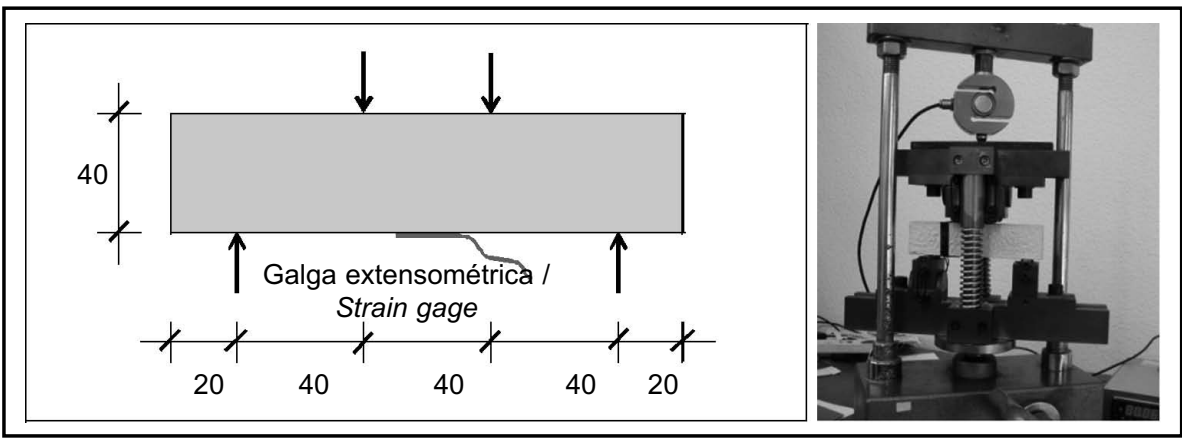

Figura 3. Esquema de los puntos de aplicación de carga y apoyos. Figure 3. Image of the load and support working points.

\section{RESULTADOS EXPERIMENTALES Y DISCUSIÓN}

En la Tabla 3 se exponen los resultados obtenidos de los END (ensayos no destructivos), para la determinación del MOE. Se han omitido los errores absolutos calculados para las determinaciones de los $\mathrm{MOE}_{\text {long }}$ y $\mathrm{MOE}_{\text {flex, }}$ dado que sólo en una probeta se ha superado el valor del $1 \%$.

Los valores de los coeficientes de variación (C.V.) expresados en \% de los resultados de cada amasada, inferiores en general al 5\%, acreditan la homogeneidad de las probetas y la bondad de las mediciones realizadas. Los resultados más dispersos, entre el 5 y el $18 \%$, corresponden al módulo de Young estático, como era de esperar dada la mayor sensibilidad a los efectos locales que presenta el procedimiento estático.

\section{EXPERIMENTAL RESULTS AND DISCUSSION}

Table 3 presents the results of the non-destructive tests for the MOE determination. Absolute errors for the $M O E_{\text {long }}$ and $M O E_{\text {flex }}$ determination have been omitted since only in one specimen the value exceeded $1 \%$.

Values of the coefficients of variation expressed in \% (C.V.\%) for the results of each mixture, in general lower than $5 \%$, prove the specimens' homogeneity and the reliability of the measurements. The more dispersed results, between 5-18\%, belong to the static Young's modulus, as it was expected since the static procedure is more sensitive to local effects.

Tabla 3 / Table 3

Resultados correspondientes a los diferentes MOE y al módulo de Young estático. Results corresponding to the different MOEs and the static Young modulus.

\begin{tabular}{|c|c|c|c|c|c|c|c|c|c|}
\hline \multicolumn{2}{|c|}{ Código / Code } & $\begin{array}{c}\text { MOE }_{\text {flex }} \\
\text { (MPa) }\end{array}$ & $\begin{array}{c}\% \text { C.V. } \\
\text { MOE flex }^{2}\end{array}$ & $\begin{array}{c}\text { MOE }_{\text {long }} \\
\text { (MPa) }\end{array}$ & $\begin{array}{c}\% \text { C.V. } \\
\text { MOE }_{\text {long }}\end{array}$ & $\begin{array}{c}\text { MOE }_{\text {us }} \\
\text { (MPa) }\end{array}$ & $\begin{array}{c}\% \text { C.V. } \\
\text { MOE }_{\text {us }}\end{array}$ & Eflex (MPa) & $\%$ C.V. Eflex. \\
\hline NHL3.5 & $1: 2.7-600$ & 7794 & 4.7 & 7678 & 10.0 & 8183 & 7.0 & 8666 & 15.6 \\
\hline NHL3.5 & $1: 4-600$ & 4515 & 2.1 & 4112 & 4.9 & 5221 & 0.5 & 4990 & 7.3 \\
\hline NHL3.5 & $1: 2.7-3600$ & 10321 & 3.4 & 9809 & 1.8 & 11114 & 2.5 & 9990 & 8.0 \\
\hline NHL3.5 & $1: 4-3600$ & 8287 & 2.9 & 7835 & 1.5 & 9302 & 2.8 & 8196 & 5.2 \\
\hline CC & $1: 2.7-600$ & 9529 & 3.0 & 9839 & 0.8 & 10462 & 2.3 & 9000 & 14.7 \\
\hline CC & $1: 4-600$ & 7726 & 1.1 & 8011 & 0.9 & 9051 & 1.8 & 9567 & 10.9 \\
\hline CC & $1: 2.7-3600$ & 13177 & 1.3 & 14059 & 2.0 & 14274 & 3.2 & 12927 & 5.5 \\
\hline CC & $1: 4-3600$ & 13230 & 2.2 & 13677 & 3.0 & 16137 & 4.7 & 12894 & 17.6 \\
\hline
\end{tabular}


En la Figura 4 se muestra el resultado de correlacionar el $\mathrm{MOE}_{\text {long }}$ con el $\mathrm{MOE}_{\text {flex }}$. Se constata la precisión y correlación entre ambos tipos de determinaciones.

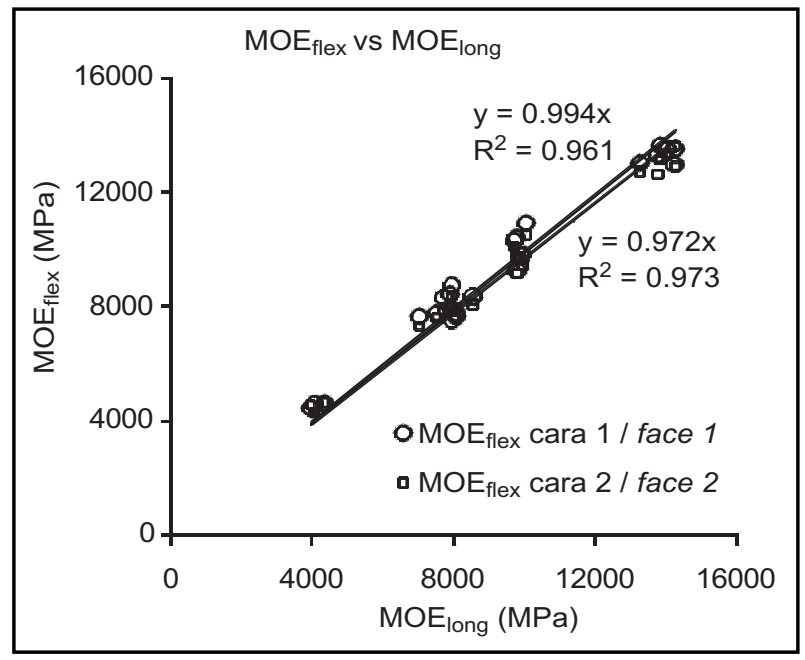

Figura 4. Correlación entre $\mathrm{MOE}_{\text {long }}$ y $\mathrm{MOE}_{\text {flex }}$. Figure 4. Correlation between $M O E_{\text {long }}$ and $M O E_{\text {flex. }}$.

Asimismo, en la Figura 5 se comparan los resultados obtenidos por impacto $\mathrm{MOE}_{\text {impact }}$ (media $\mathrm{MOE}_{\text {long }} \mathrm{y}$ $\mathrm{MOE}_{\text {flex }}$ ) con los determinados por velocidad de paso de ultrasonidos. Se constata la excelente correlación $\left(R^{2}\right.$ de $0,97$ y 0,92$)$, si bien se observa que los valores obtenidos por ultrasonidos son superiores ( 2 y $12 \%$ ) a los de impacto.

Del análisis comparado de los resultados en conjunto (Figura 6) podemos destacar la gran correlación entre los resultados del módulo de Young por flexión con los MOE por impacto o por ultrasonidos ( $R^{2}$ de 0,94 y 0,92 ).
Figure 4 shows the results of correlating $M O E_{\text {long }}$ with $M O E_{f l e x}$. The precision and correlation between both types of determinations can be confirmed.

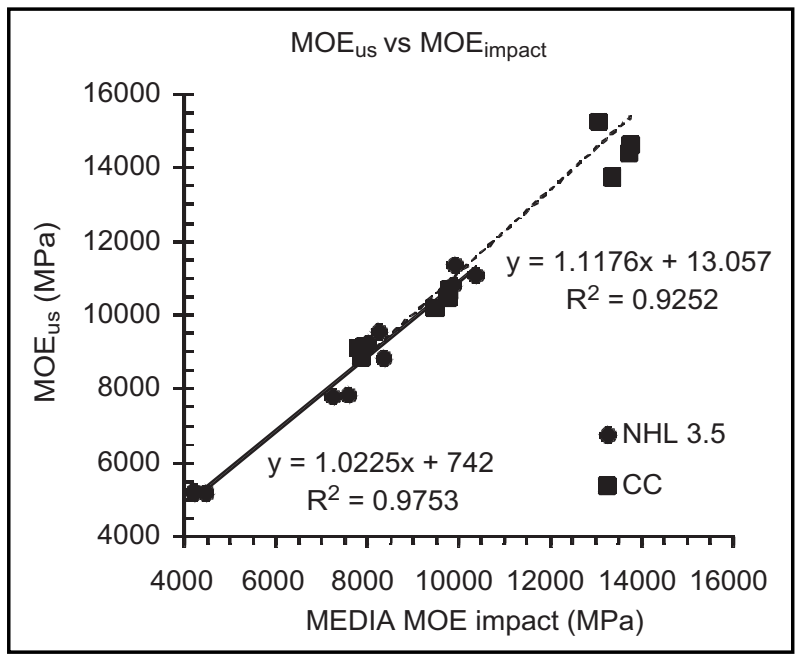

Figura 5. Correlación entre $\mathrm{MOE}_{\text {impacto }}$ y $\mathrm{MOE}_{\mathrm{us}}$. Figure 5. Correlation between $M O E_{\text {impact }}$ and $M O E_{u s}$.

In addition, Figure 5 shows a comparison of the results obtained by impact $M O E_{\text {impact }}$ (average $M O E_{\text {long }}$ and $\left.M O E_{f l e x}\right)$ to those determined by the velocity at which ultrasonic waves propagate. The correlation is excellent ( $R^{2}$ of 0.97 and 0.92 ) although the values obtained by ultrasound are clearly higher (2 and 12\%) than the impact ones.

From the comparative analysis of all the results (Figure 6), it is possible to highlight the high correlation between flexural Young's modulus and MOE by impact and ultrasound ( $R^{2}$ of 0.94 and 0.92 ).

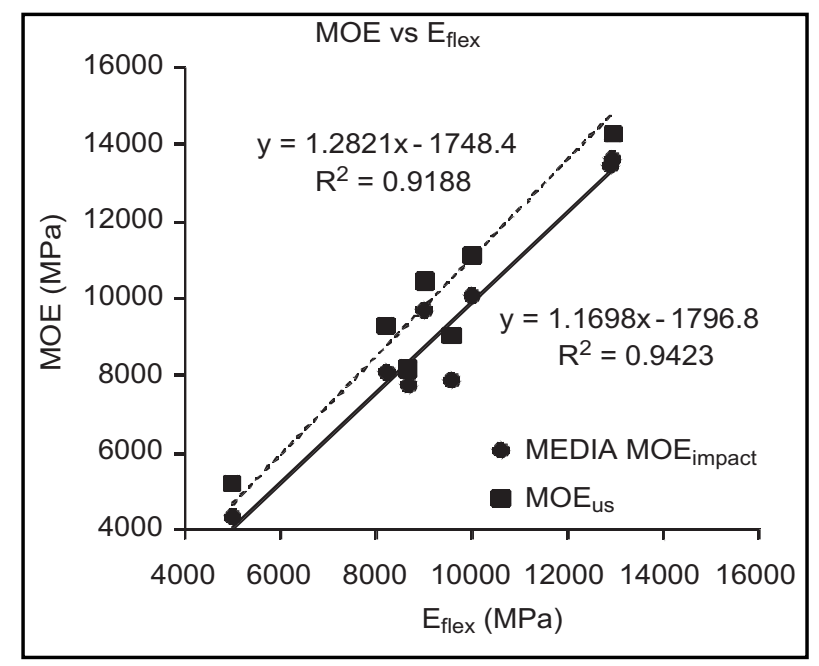

Figura 6. Relación entre los MOE determinados y $\mathrm{E}_{\text {flex}}$.

Figure 6. Relation between the determined MOEs and $E_{\text {flex. }}$ 
En los casos estudiados se pueden establecer relaciones lineales entre ambos métodos que responden a las expresiones: [5] [6]
In the cases studied, it is possible to establish linear relations between both methods that respond to the following expressions: [5] [6].

$$
\begin{gathered}
\mathrm{MOE}_{\text {impact }}=1.17 \cdot \mathrm{E}-1800 \\
\mathrm{MOE}_{\mathrm{us}}=1.28 \cdot \mathrm{E}-1750
\end{gathered}
$$

\section{CONCLUSIONES}

El método de medida del módulo de Young dinámico por excitación de vibración por impacto (MOE) resulta extraordinariamente simple. Aplicado a los morteros citados, ha permitido obtener resultados correlacionables con el otro sistema dinámico estudiado (MOE por ultrasonido) y con la determinación del módulo de Young estático a partir de ensayo de flexotracción.

Las probetas normalizadas RILEM 4x4x16 cm utilizadas en los ensayos mecánicos comunes son apropiadas para medir el MOE.

La facilidad de ejecución y la fiabilidad de las medidas, asociadas al bajo coste del equipo (un ordenador común más un micrófono), permiten pensar en una aplicabilidad extendida como herramienta de control en industrias fabricantes de morteros. También posibilita con mayor facilidad que se caractericen los morteros por su deformabilidad y no sólo por su resistencia mecánica.

Asimismo, el estudio ha permitido mostrar que, basándose en el módulo de Young dinámico obtenido experimentalmente en laboratorio para los materiales ensayados, puede encontrarse una correlación expresada en forma de una función analítica que permite determinar el correspondiente módulo estático.

Constatamos que el $\mathrm{MOE}_{\text {impact }}$ estima con mayor precisión la deformabilidad del material que el $\mathrm{MOE}_{\mathrm{us}}$, dado que las longitudes de onda generadas por la perturbación son muy superiores a las discontinuidades, lo que minimiza el efecto de no homogeneidad del material estudiado.

\section{AGRADECIMIENTOS}

A las empresas Cales de Pachs, Omya Clariana, Alfredo Pérez y Parex Morteros, por su colaboración en este trabajo.

El estudio ha sido financiado por el Ministerio de Educación y Ciencia (España), bajo los proyectos FIS200506912-C02-01, FIS2008-06335-C02-01 y FIS200611452-C03-02 y por la Generalitat de Catalunya (España) con el proyecto 2009 SGR 878.

\section{CONCLUSIONS}

The measurement method of the dynamic Young's modulus by impulse excitation by vibration is extraordinary simple to use. When applied to mortars, it is possible to obtain results that correlate with the other dynamic system studied (MOE by ultrasound) and with the determination of the static Young's modulus from the flexotraction test.

Standardized specimens RILEM $4 \times 4 \times 16 \mathrm{~cm}$ used in the ordinary mechanical tests are suitable to measure the dynamic modulus of elasticity.

The simplicity of the procedure as well as the reliability of the values obtained in the measurements, related to the low-cost of the equipment used (a simple computer and a microphone), suggest that this can be a methodology widely applied as a control tool in mortar producing companies. It also makes it possible to characterize mortars more easily by their strain behaviour and not just by their mechanical resistance.

Also, the study has made it possible to prove that, by studying the dynamic Young's module obtained experimentally in the laboratory, it is possible to find a correlation expressed as an analytical function that makes it possible to determine the corresponding static modulus.

We have verified that $M O E_{\text {impact }}$ estimates the strain of the material more accurately than $M O E_{u s}$ since the wavelengths generated by the vibration are much higher than the discontinuities, which minimizes the effect of non-homogeneity in the material under study.

\section{AKNOWLEDGEMENTS}

We would like to thank the following companies for their support in this study: Cales de Pachs, Omya Clariana, Alfredo Pérez y Parex Morteros.

This study has been financed by the Ministerio de Educación y Ciencia (Spain) as part of the FIS200506912-C02-01, FIS2008-06335-C02-01 y FIS200611452-C03-02 projects, and by the Generalitat de Catalunya (Spain) as part of the 2009 SGR 878 project. 


\section{BIBLIOGRAFÍA / BIBLIOGRAPHY}

(1) ICCROM: "Mortars, cements and grouts used in the conservation of historic buildings. Mortiers ciments et coulis utilisés dans la conservation des bâtiments historiques"; Symposium 3-16, Roma (1982).

(2) Ricardo, M. y Baettig, P.: "Determinación del módulo de elasticidad de la madera mediante vibraciones transversales", Maderas. Ciencia y tecnología, vol. 3(1-2), pp. 44-51 (2001).

(3) Fakopp: Acoustic tomography for tree evaluation, www.fakopp.com

(4) Nagy, A.: "Determination of E-modulus of young concrete with nondestructive method", J. Mater. Civ. Eng., 9(1), 15-20 (1997). doi:10.1061/(ASCE)0899-1561(1997)9:1(15)

(5) "Standard Test Method for Dynamic Young's Modulus, Shear Modulus, and Poisson's Ratio by Impulse Excitation of Vibration", ASTM Standard E1876-01, (2001).

(6) Schmidt, R.; Wicher, V.; Tilgner, R.: "Young's modulus of Goulding compounds mesured with a resonante method", Polymer Testing, vol. 24, 197-203 (2005). doi:10.1016/j.polymertesting.2004.08.010

(7) Norma UNE-EN 14146: "Métodos de ensayo para piedra natural. Determinación del módulo de elasticidad dinámico (con la medida de la frecuencia de resonancia fundamental)" (2004).

(8) Norma UNE-EN ISO 12680-1: "Métodos de ensayo para productos refractarios. Parte 1: Determinación del módulo de Young dinámico (MOE) por excitación de la vibración por impulso" (2007).

(9) Norma UNE-EN 1015-3: "Métodos de ensayo de los morteros para albañilería. Parte 3: Determinación de la consistencia del mortero fresco (por la mesa de sacudidas)" (2000).

(10) Hernández, M. G.; Anaya, J. J.; Izquierdo, M. A. G.; Ullate, L. G.: "Application of micromechanics to the characterization of mortar by ultrasound", Ultrasonics, vol. 40 (2002). 